Check for updates

Cite this: RSC Adv., 2018, 8, 22498

Received 26th April 2018

Accepted 13th June 2018

DOI: $10.1039 / \mathrm{c} 8 \mathrm{ra03605e}$

rsc.li/rsc-advances

\title{
Tandem four-component reaction for efficient synthesis of dihydrothiophene with substituted amino acid ethyl esters $\uparrow$
}

\author{
Jing Sun, Yu Zhang and Chao-Guo Yan (D) * \\ The one-pot four-component reaction of aromatic aldehydes, malononitrile, 1,3-thiazolidinedione and ethyl \\ glycinate hydrochloride in ethanol in the presence of triethylamine afforded trans-dihydrothiophene \\ ureidoformamide derivatives in moderate to good yields. The other $\alpha$-amino acid ethyl esters resulted in \\ the corresponding diastereoisomeric dihydrothiophene derivatives with various molecular ratios. The \\ functionalized thiophene derivatives were also successfully prepared by sequential dehydrogenation \\ reaction with $D D Q$.
}

\section{Introduction}

The heterocyclic nucleus 2,3-dihydrothiophene is widely distributed in many natural products, bioactive compounds possessing useful medicinal and biological activities. ${ }^{1-3}$ On the other hand, 2,3-dihydrothiophenes are also useful synthetic precursors for many compounds including thiophenes, thionucleoside derivatives, and penicillin mimics. ${ }^{4,5}$ Therefore, the development of efficient synthetic methodologies for functionalized 2,3-dihydrothiophenes has attracted continuous interest in the field of organic and medicinal chemistry. ${ }^{6,7}$ Although many elegant strategies toward the construction of dihydrothiophenes have been successfully accessed, green approaches to functionalized dihydrothiophenes with high atomic efficiency and good feasibility to assemble various substitution patterns is still highly desirable. ${ }^{89}$ Recently, we successfully revealed a novel domino four-component reaction of 1,3-thiazolidinedione, malononitrile, aromatic aldehydes, and amines for efficient synthesis of dihydrothiophene derivatives. This reaction was very unique because the ring-opening/recyclization process occurs unexpectedly at the ring of 1,3-thiazolidinedione with various amines. ${ }^{\mathbf{1 0}}$ In the past few years, for developing "greener" processes and ascertaining limitations of this useful transformation, this four-component reaction was also carried out in a functional ionic liquid, under ultrasound irradiation and under catalyst-free conditions as well as others. ${ }^{11,12}$ For further demonstrating the synthetic value of this

College of Chemistry \& Chemical Engineering, Yangzhou University, Yangzhou 225002, China.E-mail: cgyan@yzu.edu.cn

$\dagger$ Electronic supplementary information (ESI) available: ${ }^{1} \mathrm{H}$ and ${ }^{13} \mathrm{C}$ NMR spectra for all new compounds are available. Crystallographic data 1b (CCDC 1823979), 1d (CCDC 1823980), 1h (CCDC 1848361), 2a (CCDC 1823981), 2 g (CCDC 1823982), $2 \mathrm{~h}$ (CCDC 1823983), 2m (CCDC 1823984), 3a (CCDC 1823985), 3d (CCDC 1823986), 3g (CCDC 1823987) have been deposited at the Cambridge Crystallographic Database Centre (http://www.ccdc.cam.ac.uk). For ESI and crystallographic data in CIF or other electronic format see DOI: 10.1039/c8ra03605e four-component reaction, we successfully employed several $\alpha$ amino acid ethyl ester hydrochlorides as the amino component, and herein we wish to report the efficient synthesis of dihydrothiophenes and thiophenes with substituted $\alpha$-amino acid ethyl esters.

\section{Results and discussions}

Initially, a mixture of benzaldehyde, malononitrile, 1,3-thiazolidinedione and ethyl glycinate hydrochloride in ethanol in the presence of triethylamine was stirred at room temperature according to the previously established reaction conditions. The reaction resulted in a complicate mixture of products and the desired product 1a was only obtained in very low yields. Then, a one-pot two-step reaction procedure was employed. After carrying out the reaction of benzaldehyde with malononitrile in ethanol in the presence of triethylamine for about one hour, 1,3thiazolidinedione and ethyl glycinate hydrochloride was added to the reaction system. Then, the reaction was conducted at 40$50{ }^{\circ} \mathrm{C}$ for about six hours. The substituted dihydrothiophene 1a could be prepared in 59\% yield. Under this convenient one-pot two-step reaction procedure, other aromatic aldehydes were employed in the reaction and the corresponding dihydrothiophene derivatives $\mathbf{1 b} \mathbf{- 1} \mathbf{g}$ were obtained in moderate to good yields (Table 1). The substituent on the aryl group showed little effect on the yields of the products. Thiophene-2carbaldehyde can be used in the reaction to give the desired product $1 \mathrm{~h}$ in $60 \%$ yield. However, the similar reactions with aliphatic aldehydes always resulted in complicate mixture of products. The structures of the products $\mathbf{1 a - 1 h}$ were fully characterized by various spectroscopies. Because there are two asymmetric carbon atoms in the obtained dihydrothiophenes, both cis-and trans-isomers might be formed in the reaction. The ${ }^{1} \mathrm{H}$ NMR spectra of the $\mathbf{1 a - 1 h}$ usually displayed one set of absorptions, which indicated that only one diastereoisomer 
Table 1 Synthesis of substituted dihydrothiophenes $1 \mathrm{a}-1 \mathrm{~g}^{a}$

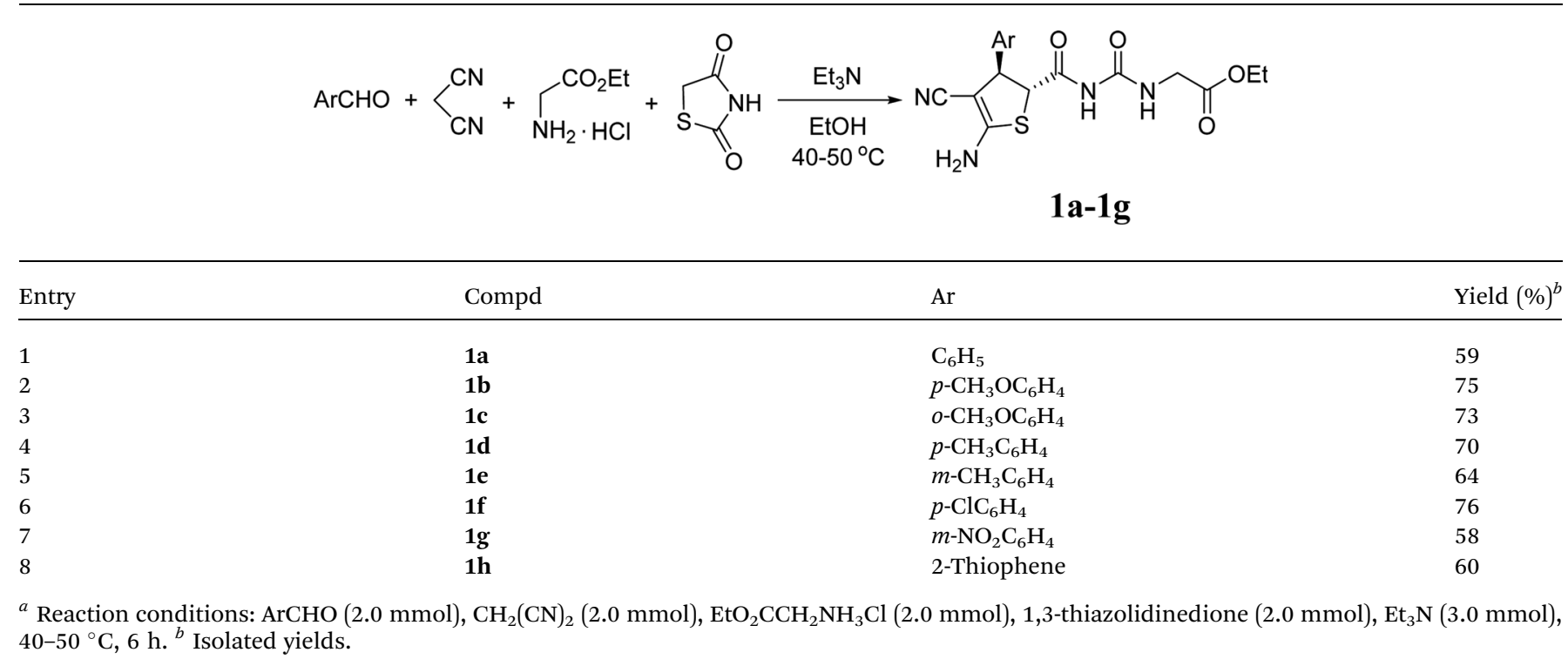
$40-50{ }^{\circ} \mathrm{C}, 6 \mathrm{~h}^{b}{ }^{b}$ Isolated yields.

existed in the obtained products. In order to determine the relative configuration of the dihydrothiophenes, the single crystal structures of the compounds $\mathbf{1 b}$ (Fig. 1), $\mathbf{1 d}$ and $\mathbf{1 h}$ (Fig. s1 and s2 $\dagger$ ) were successfully determined. It can be seen that they have trans-configuration, in which the aryl group and the ureido group stand at trans-positions in the ring of dihydrothiophene. A intramolecular $\mathrm{H}$-bond is formed between the carbonyl group and amino group in the molecule. This result is concordance to our previously reported four-component reactions with various aliphatic or aromatic amines, in that only trans-1,2-disubstituted dihydrothiophene derivatives were predominately formed in the reaction. ${ }^{10}$

In order to develop the scope of the reaction, various $\alpha$-amino acid ethyl esters were employed in the four-component reaction. The results are summaries in Table 2. It can be seen that ethyl DL-alaninate, L-serine, L-isoleucinate, L-phenylalaninate, and L-hyperphenylalaninate gave the expected substituted dihydrothiophenes $\mathbf{2 a - 2 n}$ in moderate yields. The substituted dihydrothiophenes $\mathbf{2 a - 2 n}$ have two asymmetric carbon atoms in ring of dihydrothiophene and one chiral carbon atom in the scaffold of amino acid. ${ }^{1} \mathrm{H}$ and ${ }^{13} \mathrm{C}$ NMR spectra indicated that there is only one diastereoisomer in the products $\mathbf{2 a - 2 f}$, which were derived from the reactions of DL-alaninate, L-serine, L-isoleucinate and $\mathrm{L}-\mathrm{phenylalaninate.} \mathrm{However,} \mathrm{there} \mathrm{are} \mathrm{two} \mathrm{diaste-}$ reoisomers with nearly $1: 1$ molar ratio existing in the products $2 \mathbf{g}-2 \mathbf{n}$. The two diastereoisomers have very similar polarity and cannot be separated by column chromatography. The single crystal structures of the compounds $2 \mathbf{a}$ (Fig. 2), $2 \mathbf{g}$, $2 \mathbf{h}$ and $\mathbf{2 m}$ (Fig. s3-s5†) were determined by X-ray diffraction. The two substituents on the ring of dihyrothiophene still exist on the trans-positions in four single crystals as that of the above products 1a-1h. Therefore, the two diastereoisomers were clearly come from the different relative configuration of the terminal

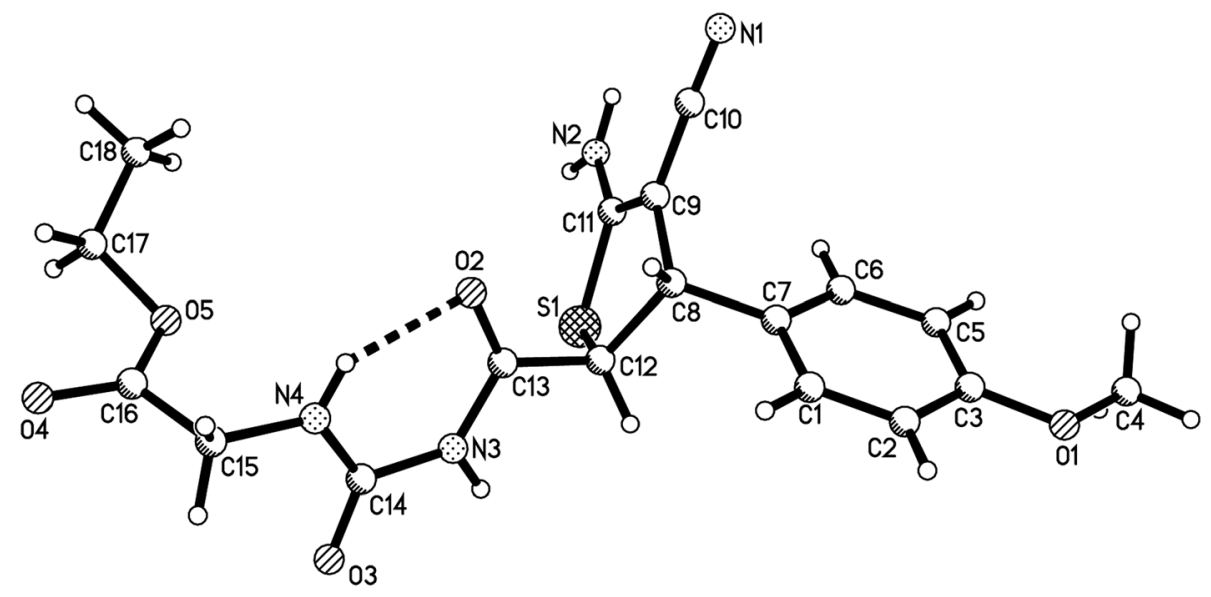

Fig. 1 Crystal structure of the compound 1b. 
Table 2 Synthesis of substituted dihydrothiophenes $2 \mathrm{a}-2 \mathrm{n}^{a}$<smiles>[R]C(N)C(=O)OCC</smiles>

\begin{tabular}{|c|c|c|c|c|}
\hline Entry & Compd & $\mathrm{Ar}$ & $\mathrm{R}$ & Yield $(\%)^{b}$ \\
\hline 1 & $2 a$ & $p-\mathrm{CH}_{3} \mathrm{OC}_{6} \mathrm{H}_{4}$ & Me & 68 \\
\hline 2 & $2 \mathbf{b}$ & $m-\mathrm{NO}_{2} \mathrm{C}_{6} \mathrm{H}_{4}$ & $\mathrm{Me}$ & 55 \\
\hline 3 & $2 \mathrm{c}$ & $p-\mathrm{CH}_{3} \mathrm{C}_{6} \mathrm{H}_{4}$ & $\mathrm{CH}_{2} \mathrm{OH}$ & 63 \\
\hline 4 & $2 d$ & $p-\mathrm{CH}_{3} \mathrm{OC}_{6} \mathrm{H}_{4}$ & $\operatorname{Sec}-\mathrm{Bu}$ & 68 \\
\hline 5 & $2 e$ & $p-\mathrm{CH}_{3} \mathrm{C}_{6} \mathrm{H}_{4}$ & $\mathrm{Sec}-\mathrm{Bu}$ & 64 \\
\hline 6 & $2 f$ & $\mathrm{C}_{6} \mathrm{H}_{5}$ & $\mathrm{Bn}$ & 48 \\
\hline 7 & $2 g$ & $p-\mathrm{CH}_{3} \mathrm{OC}_{6} \mathrm{H}_{4}$ & $\mathrm{Bn}$ & $62(53: 47)$ \\
\hline 8 & $2 h$ & $m-\mathrm{CH}_{3} \mathrm{OC}_{6} \mathrm{H}_{4}$ & $\mathrm{Bn}$ & $60(51: 49)$ \\
\hline 9 & $2 \mathbf{i}$ & $o-\mathrm{CH}_{3} \mathrm{OC}_{6} \mathrm{H}_{4}$ & $\mathrm{Bn}$ & $56(51: 49)$ \\
\hline 10 & $2 j$ & $p-\mathrm{CH}_{3} \mathrm{C}_{6} \mathrm{H}_{4}$ & $\mathrm{Bn}$ & $55(52: 48)$ \\
\hline 11 & $2 k$ & $p-\mathrm{ClC}_{6} \mathrm{H}_{4}$ & $\mathrm{Bn}$ & $53(53: 47)$ \\
\hline 12 & 21 & $p-\mathrm{BrC}_{6} \mathrm{H}_{4}$ & $\mathrm{Bn}$ & $55(53: 47)$ \\
\hline 13 & $2 \mathrm{~m}$ & $p-\mathrm{CH}_{3} \mathrm{OC}_{6} \mathrm{H}_{4}$ & $\mathrm{CH}_{2} \mathrm{CH}_{2} \mathrm{Ph}$ & $67(54: 46)$ \\
\hline 14 & $2 n$ & $p-\mathrm{CH}_{3} \mathrm{OC}_{6} \mathrm{H}_{4}$ & $\mathrm{CH}_{2} \mathrm{C}_{6} \mathrm{H}_{5} \mathrm{OH}-p$ & $57(55: 45)$ \\
\hline
\end{tabular}

${ }^{a}$ Reaction conditions: $\mathrm{ArCHO}(2.0 \mathrm{mmol}), \mathrm{CH}_{2}(\mathrm{CN})_{2}(2.0 \mathrm{mmol}), \alpha$-amino acid ethyl esters $(2.0 \mathrm{mmol}), 1,3$-thiazolidinedione (2.0 mmol), Et ${ }_{3} \mathrm{~N}(3.0$ $\mathrm{mmol}), 40-50{ }^{\circ} \mathrm{C}, 6 \mathrm{~h} .{ }^{b}$ Isolated yields.

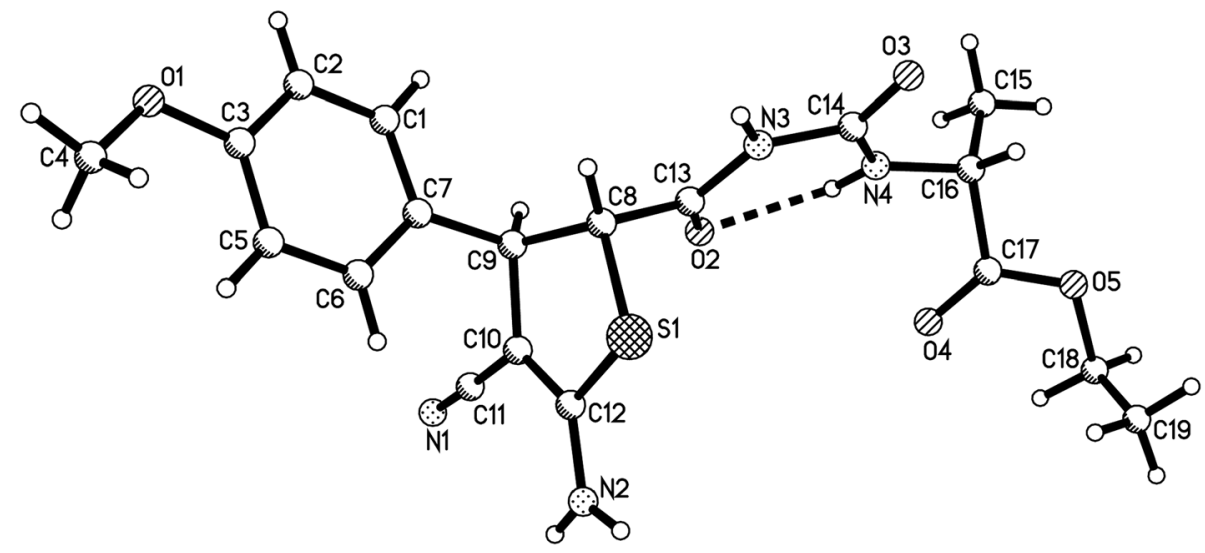

Fig. 2 Crystal structure of the compound 2a.

substituted $\alpha$-amino acid ethyl ester to the ring of dihydrothiophene (Scheme 1).

For demonstrating the synthetic values of the fourcomponent reaction, the aromatization of the obtained dihydrothiophenes was performed. When the fourcomponent reaction in the presence of triethylamine was finished, the dehydrogenation reaction with a lightly excess of DDQ was carried out at elevated temperature. After workup, the corresponding thiophene derivatives $\mathbf{3 a}-\mathbf{3} \mathbf{j}$ were prepared in good yields. Due to formation of aromatized thiophene derivatives, ${ }^{1} \mathrm{H}$ and ${ }^{13} \mathrm{C}$ NMR spectra clearly showed one set of the characterized absorptions, which also indicated that there<smiles>[R]c1c(C(=O)NC(=O)N[C@@H]([R])C(=O)OCC)sc(N)c1Br</smiles><smiles></smiles>

Scheme 1 Illustration of two diastereoisomers for compounds $2 \mathrm{a}-2 \mathrm{n}$. 
is only one diastereoisomer in the products $\mathbf{3 a}-\mathbf{3} \mathbf{j}$. The single crystal structures of the compounds $\mathbf{3 a}$ (Fig. 3), 3d, $\mathbf{3 g}$ (Fig. s5 and $56 \dagger$ ) were determined by X-ray diffraction method (Table 3).

For explaining the formation of the dihydrothiophene derivatives, a plausible reaction mechanism was proposed on the basis of the previously reported reactions. ${ }^{10}$ Firstly, the base catalyzed condensation reaction of aromatic aldehyde with malononitrile afforded arylidene malononitrile (A). Secondly, Michael addition of the in situ generated carbanion of 1,3-thiazolidinedione resulted in the adduct (B). In the meantime, free $\alpha$-amino acid ethyl ester was produced by the neutralization of triethylamine with $\alpha$-amino acid ethyl ester hydrochloride. Then the nucleophilic attack of amino group

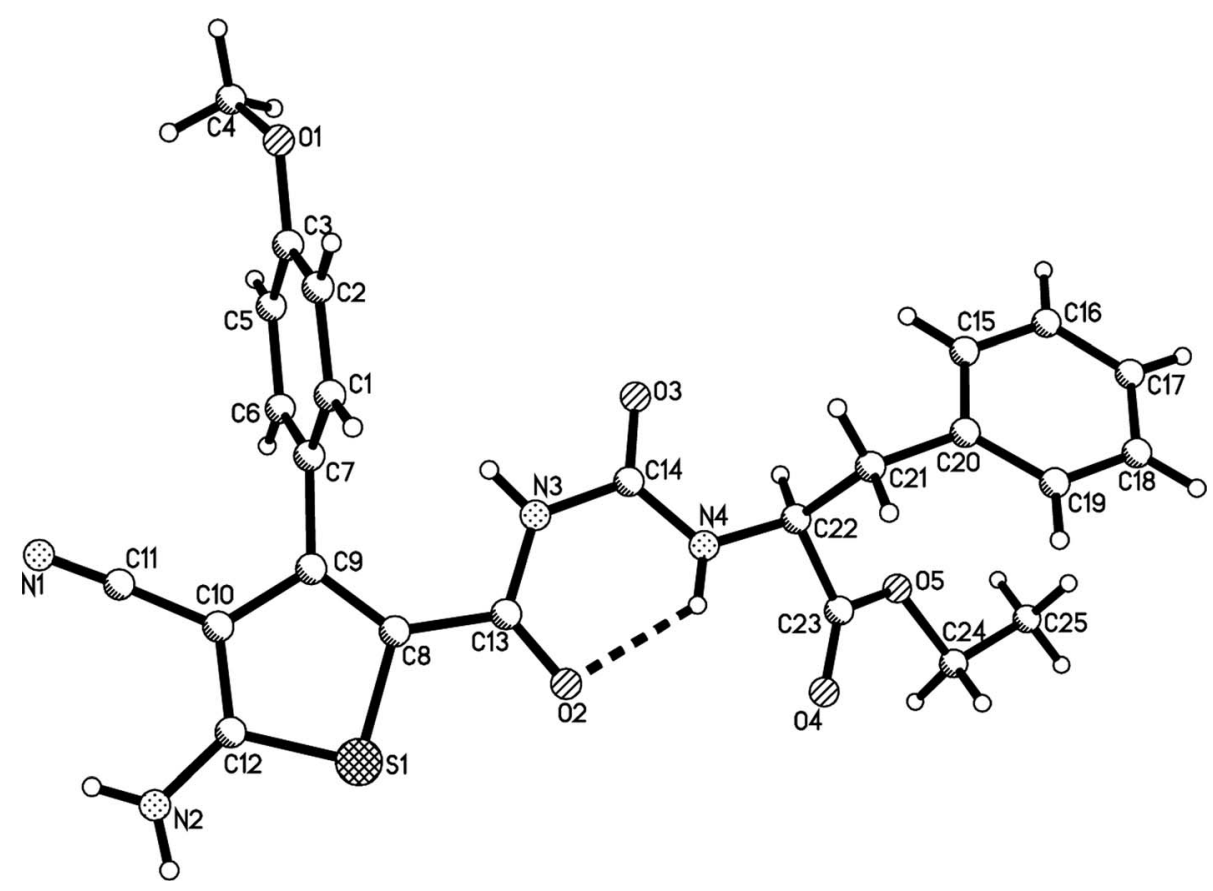

Fig. 3 Crystal structure of the compound $3 a$.

Table 3 Synthesis of thiophene derivatives $3 a-3 j^{a}$

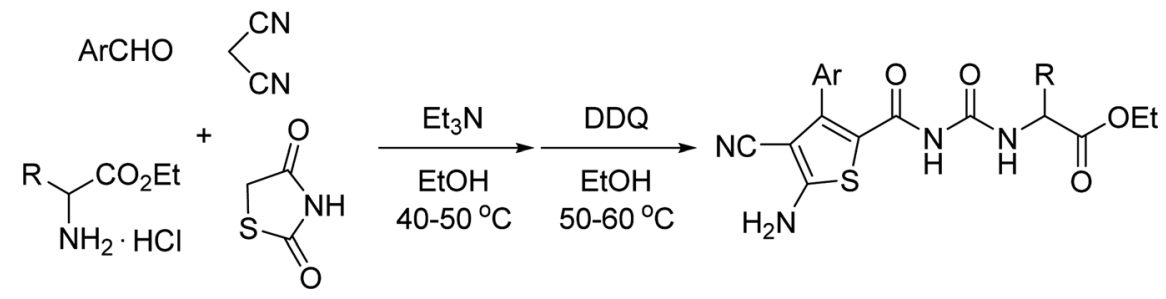

\begin{tabular}{|c|c|c|c|c|}
\hline Entry & Compd & $\mathrm{Ar}$ & $\mathrm{R}$ & Yield $(\%)^{b}$ \\
\hline 1 & $3 a$ & $p-\mathrm{CH}_{3} \mathrm{OC}_{6} \mathrm{H}_{4}$ & $\mathrm{Bn}$ & 62 \\
\hline 2 & $3 \mathbf{b}$ & $m-\mathrm{CH}_{3} \mathrm{OC}_{6} \mathrm{H}_{4}$ & $\mathrm{Bn}$ & 60 \\
\hline 4 & $3 d$ & $p-\mathrm{CH}_{3} \mathrm{C}_{6} \mathrm{H}_{4}$ & $\mathrm{Bn}$ & 55 \\
\hline 5 & $3 e$ & $p-\mathrm{ClC}_{6} \mathrm{H}_{4}$ & $\mathrm{Bn}$ & 63 \\
\hline 6 & $3 f$ & $p-\mathrm{BrC}_{6} \mathrm{H}_{4}$ & $\mathrm{Bn}$ & 55 \\
\hline 9 & $3 \mathbf{i}$ & $p-\mathrm{CH}_{3} \mathrm{OC}_{6} \mathrm{H}_{4}$ & $\mathrm{CH}_{2} \mathrm{CH}_{2} \mathrm{Ph}$ & 58 \\
\hline 10 & $3 \mathbf{j}$ & $p-\mathrm{CH}_{3} \mathrm{OC}_{6} \mathrm{H}_{4}$ & $\mathrm{CH}_{2} \mathrm{C}_{6} \mathrm{H}_{4} \mathrm{OH}-p$ & 66 \\
\hline
\end{tabular}

${ }^{a}$ Reaction conditions: 1 . ArCHO $(2.0 \mathrm{mmol}), \mathrm{CH}_{2}(\mathrm{CN})_{2}(2.0 \mathrm{mmol}), \alpha$-amino acid ethyl ester $(2.0 \mathrm{mmol}), 1,3$-thiazolidinedione (2.0 mmol), Et ${ }_{3} \mathrm{~N}(3.0$ $\mathrm{mmol}), 40-50{ }^{\circ} \mathrm{C}, 6 \mathrm{~h} ; 2$. DDQ $(2.2 \mathrm{mmol}), 60^{\circ} \mathrm{C}, 4 \mathrm{~h} .{ }^{b}$ Isolated yields. 


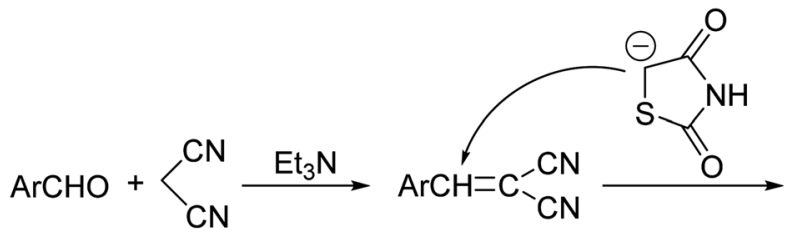

(A)<smiles>CC(C#N)C(Br)C1SC(=O)NC1=O</smiles>

(B)

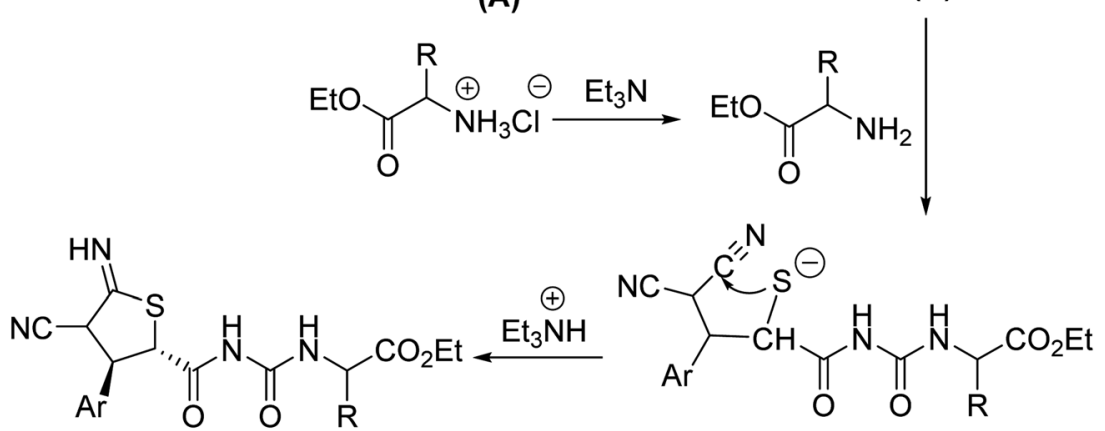

(D)

(C)<smiles>[R]C(NC(=O)NC(=O)[C@H]1SC(N)=C(C#N)[C@@H]1[Te])C(=O)NC(=O)c1sc(N)c(C#N)c1[Al]</smiles>

Scheme 2 Proposed reaction mechanism for the four-component reaction.

to the carbonyl group of intermediate (B) resulted in the ringopening sulfide anion (C). The intramolecular nucleophilic addition of sulfide anion to one cyano group with sequential protonation gave the imino-substituted dihydrothiophene (D), which in turn converted to the dihydrothiophene derivatives 1 or 2 through imino-enamino tautomerization. The thermodynamically stable trans-isomer was predominately formed in the cyclization process. At last, DDQ oxidation of dihydrophene resulted in the thiophene product 3 (Scheme 2).

\section{Conclusion}

In summary, we have investigated the base promoted fourcomponent reaction of aromatic aldehydes, malononitrile, 1,3-thiazolidinedion and $\alpha$-amino acid ethyl ester hydrochlorides and provided efficient synthetic protocol for trans-2,3dihydrothiophene and corresponding thiophene derivatives with scaffold of $\alpha$-amino acid ethyl esters. This reaction has the advantages of using readily available chemicals, mild reaction conditions, satisfactory yields, high diastereoselectivity and atomic economy. More importantly, this reaction not only developed the variety of our previously established novel fourcomponent reaction, but also further demonstrated the synthetic applications for diverse dihydrothiophene and thiophene derivatives. The potential application of this multicomponent reaction in organic and medicinal chemistry might be significant.

\section{Experimental section}

\subsection{General procedure for the preparation of the dihydrothiophene derivatives $1 \mathrm{a}-1 \mathrm{~g}$ and $2 \mathrm{a}-2 \mathrm{~m}$}

A mixture of aromatic aldehyde $(2.0 \mathrm{mmol})$ and malononitrile $(2.0 \mathrm{mmol})$ and triethylamine $(3.0 \mathrm{mmol})$ in ethanol $(20.0 \mathrm{~mL})$ was stirred at room temperature for one hour. Then, 1,3-thiazolidinedione $(2.0 \mathrm{mmol})$ and $\alpha$-amino acid ethyl ester hydrochloride $(2.0 \mathrm{mmol})$ was added. The resulting mixture was stirred at about $40-50{ }^{\circ} \mathrm{C}$ for six hours. After removing the solvent by rotatory evaporation at reduced pressure, the residue was subjected to column chromatography with light petroleum and ethyl acetate $(\mathrm{v} / \mathrm{v}=2: 1)$ as eluent to give pure product for analysis.

4.1.1 Ethyl ((5-amino-4-cyano-3-phenyl-2,3-dihydrothiophene2-carbonyl)carbamoyl)glycinate (1a). Yellow solid, 49\%, mp 188$190{ }^{\circ} \mathrm{C} ;{ }^{1} \mathrm{H}$ NMR (400 MHz, DMSO- $\left.d_{6}\right) \delta: 10.53(\mathrm{~s}, 1 \mathrm{H}, \mathrm{NH}), 8.50$ (s, $1 \mathrm{H}, \mathrm{NH}), 7.40-7.36(\mathrm{~m}, 2 \mathrm{H}, \mathrm{ArH}), 7.32-7.28(\mathrm{~m}, 3 \mathrm{H}, \mathrm{ArH}), 7.20(\mathrm{~s}$, $\left.2 \mathrm{H}, \mathrm{NH}_{2}\right), 4.57(\mathrm{~d}, J=3.2 \mathrm{~Hz}, 1 \mathrm{H}, \mathrm{CH}), 4.14-4.09(\mathrm{~m}, 3 \mathrm{H}, \mathrm{CH}), 3.94$ $(\mathrm{d}, J=6.0 \mathrm{~Hz}, 2 \mathrm{H}, \mathrm{CH}), 1.20\left(\mathrm{t}, J=7.2 \mathrm{~Hz}, 3 \mathrm{H}, \mathrm{CH}_{3}\right) ;{ }^{13} \mathrm{C}$ NMR $(100$ MHz, DMSO- $\left.d_{6}\right) \delta: 171.9,170.0,162.1,153.5,141.8,129.1,127.9$, 127.5, 118.6, 70.7, 61.0, 55.6, 52.0, 41.7, 14.5; IR (KBr) $\nu: 3408,3369$, 3317, 3193, 3097, 2973, 2204, 1753, 1701, 1654, 1591, 1548, 1415, 
1356, 1321, 1248, 1210, 1135, 1019, 977, $856 \mathrm{~cm}^{-1}$; MS (m/z): HRMS (ESI) calcd for $\mathrm{C}_{17} \mathrm{H}_{18} \mathrm{~N}_{4} \mathrm{O}_{4} \mathrm{~S}\left([\mathrm{M}+\mathrm{Na}]^{+}\right)$: 397.1049, found: 397.0938 .

4.1.2 Ethyl ((5-amino-4-cyano-3-(4-methoxyphenyl)-2,3dihydrothiophene-2-carbonyl)carbamoyl)alaninate (2a). White solid, 68\%, mp 218-220 ${ }^{\circ} \mathrm{C} ;{ }^{1} \mathrm{H}$ NMR (400 MHz, DMSO- $d_{6}$ ) $\delta$ : 10.58 (s, 1H, NH), 8.52 (s, 1H, NH), 7.23-7.18 (m, 4H, ArH, $\mathrm{NH}_{2}$ ), $6.93(\mathrm{~d}, J=8.8 \mathrm{~Hz}, 2 \mathrm{H}, \mathrm{ArH}), 4.51-4.50(\mathrm{~m}, 1 \mathrm{H}, \mathrm{CH}), 4.34-4.27$ (m, 1H, CH), $4.12(\mathrm{~m}, 2 \mathrm{H}, \mathrm{CH}), 4.05(\mathrm{~s}, 2 \mathrm{H}, \mathrm{CH}), 3.75(\mathrm{~s}, 3 \mathrm{H}$, $\left.\mathrm{OCH}_{3}\right), 1.36\left(\mathrm{~d}, J=7.2 \mathrm{~Hz}, 3 \mathrm{H}, \mathrm{CH}_{3}\right), 1.20(\mathrm{t}, J=7.2 \mathrm{~Hz}, 3 \mathrm{H}$, $\left.\mathrm{CH}_{3}\right) ;{ }^{13} \mathrm{C}$ NMR $\left(100 \mathrm{MHz}, \mathrm{DMSO}-d_{6}\right) \delta: 172.5,172.3,161.7$, 159.1, 152.8, 133.6, 128.6, 118.6, 114.5, 71.1, 61.2, 55.8, 55.5, 51.4, 48.6, 18.0, 14.4; IR (KBr) $\nu: ~ 3449,3328,3227,3155,2968$, 2848, 2180, 1740, 1695, 1624, 1582, 1547, 1506, 1348, 1309, 1252, 1193, 1030, $829 \mathrm{~cm}^{-1}$; MS $(\mathrm{m} / \mathrm{z})$ : HRMS (ESI) calcd for $\mathrm{C}_{19} \mathrm{H}_{22} \mathrm{~N}_{4} \mathrm{O}_{5} \mathrm{~S}\left([\mathrm{M}+\mathrm{Na}]^{+}\right)$: 441.1311, found: 441.1206 .

\subsection{General procedure for the preparation of the thiophene} derivatives $3 \mathbf{a}-\mathbf{3} \mathbf{j}$

A mixture of aromatic aldehyde $(2.0 \mathrm{mmol})$ and malononitrile $(2.0 \mathrm{mmol})$ and triethylamine $(3.0 \mathrm{mmol})$ in ethanol $(20.0 \mathrm{~mL})$ was stirred at room temperature for one hour. Then, 1,3-thiazolidinedione $(2.0 \mathrm{mmol})$ and $\alpha$-amino acid ethyl ester hydrochloride $(2.0 \mathrm{mmol})$ was added. The resulting mixture was stirred at about $40-50{ }^{\circ} \mathrm{C}$ for six hours. Then, DDQ $(2.2 \mathrm{mmol})$ was added. The mixture was stirred at $50-60{ }^{\circ} \mathrm{C}$ for additional for four hours. After removing the solvent by rotatory evaporation at reduced pressure, the residue was subjected to column chromatography with light petroleum and ethyl acetate $(\mathrm{v} / \mathrm{v}=$ $2: 1)$ as eluent to give pure product for analysis.

4.2.1 Ethyl ((5-amino-4-cyano-3-(4-methoxyphenyl)thiophene -2-carbonyl)carbamoyl)phenylalaninate (3a). Yellow solid, 62\%, mp 177-179 ${ }^{\circ} \mathrm{C} ;{ }^{1} \mathrm{H}$ NMR (400 MHz, DMSO- $\left.d_{6}\right) \delta: 8.49(\mathrm{~d}, J=$ $7.6 \mathrm{~Hz}, 1 \mathrm{H}, \mathrm{NH}), 8.10$ (d, $\left.J=8.0 \mathrm{~Hz}, 3 \mathrm{H}, \mathrm{NH}, \mathrm{NH}_{2}\right), 7.35$ (d, $J=$ $8.4 \mathrm{~Hz}, 2 \mathrm{H}, \mathrm{ArH}), 7.31-7.21$ (m, 3H, ArH), 7.13 (d, $J=8.8 \mathrm{~Hz}, 2 \mathrm{H}$, $\mathrm{ArH}), 7.08$ (d, $J=8.8 \mathrm{~Hz}, 2 \mathrm{H}, \mathrm{ArH}), 4.51-4.46(\mathrm{~m}, 1 \mathrm{H}, \mathrm{CH}), 4.06$ (q, $=7.2 \mathrm{~Hz}, 2 \mathrm{H}, \mathrm{CH}), 3.82\left(\mathrm{~s}, 3 \mathrm{H}, \mathrm{OCH}_{3}\right), 3.07-2.97(\mathrm{~m}, 2 \mathrm{H}, \mathrm{CH}), 1.13$ $\left(\mathrm{t}, J=7.2 \mathrm{~Hz}, 3 \mathrm{H}, \mathrm{CH}_{3}\right) ;{ }^{13} \mathrm{C}$ NMR $\left(100 \mathrm{MHz}, \mathrm{DMSO}-d_{6}\right) \delta: 171.2$, 167.6, 161.9, 160.6, 152.0, 146.0, 136.7, 130.8, 129.5, 128.7, 127.2, 124.4, 115.3, 114.9, 111.9, 89.5, 61.3, 55.7, 54.2, 37.4, 14.3; IR (KBr) $\nu: 3438,3373,3281,3168,2967,2211,1730,1680,1648,1516$, 1467, 1412, 1316, 1256, 1181, 1078, 1024, 876, $840 \mathrm{~cm}^{-1}$; MS (m/z): HRMS (ESI) calcd for $\mathrm{C}_{25} \mathrm{H}_{24} \mathrm{~N}_{4} \mathrm{O}_{5} \mathrm{~S}\left([\mathrm{M}+\mathrm{Na}]^{+}\right)$: 515.1467 , found: 515.1357.

\section{Conflicts of interest}

There are no conflicts to declare.

\section{Acknowledgements}

This work was financially supported by the National Natural Science Foundation of China (Grant No. 21572196) and the Priority Academic Program Development of Jiangsu Higher Education Institutions. We also thank Analysis and Test Center of Yangzhou University providing instruments for analysis.

\section{References}

1 (a) W. Zhu, Y. Chong, H. Choo, J. Mathews, R. F. Schinazi and C. K. Chu, Synthesis, Structure-Activity Relationships, and Mechanism of Drug Resistance of $\mathrm{D}^{-}$and $\mathrm{L}-\beta-3^{\prime}$-Fluoro$2^{\prime}, 3^{\prime}$-unsaturated-4'-thionucleosides as Anti-HIV Agents, J. Med. Chem., 2004, 47, 1631-1640; (b) J. Zempleni, S. S. K. Wijeratne and Y. I. Hassan, BioFactors, 2009, 35, 36-46; (c) S. Benetti, C. D. Risi, G. P. Pollini and V. Zanirato, Synthetic Routes to Chiral Nonracemic and Racemic Dihydro- And Tetrahydrothiophenes, Chem. Rev., 2012, 112, 2129-2163; (d) K. Haraguchi, H. Shimada, H. Tanaka, et al., J. Med. Chem., 2008, 51, 1885-1893.

2 (a) M. Modica, M. Santagati, S. Guccione, F. Russo, A. Cagnotto, M. Goegan and T. Mennini, Design, synthesis and binding properties of novel and selective 5-HT3 and 5HT4 receptor ligands, Eur. J. Med. Chem., 2000, 35, 10651079; (b) C. Wu, E. R. Decker, N. Blok, H. Bui, T. J. You, J. Wang, A. R. Bourgoyne, V. Knowles, K. L. Berens, G. W. Holland, T. A. Brock and R. A. F. Dixon, Discovery, modeling, and human pharmacokinetics of $\mathrm{N}$-(2-Acetyl-4,6dimethylphenyl)-3-(3,4-dimethylisoxazol-5-ylsulfamoyl) thiophene-2-carboxamide (TBC3711), a second generation, ETA selective, and orally bioavailable endothelin antagonist, J. Med. Chem., 2004, 47, 1969-1986; (c) M. N. Narule, Synthesis of some new $1-N-\left(\beta-D^{-}\right.$ glucopyranosyl)-2-((1-phenyl-5-aryl)pyrazol-3-yl)pyrroles and their biological activities, Pharma Chem., 2011, 3, 38-47.

3 (a) G. Loire, D. Prim, B. Andrioletti, E. Rose, A. Persoons, S. Sioncke and J. Vaissermann, Rational synthesis of regioregular oligothiophenes via palladium catalyzed coupling reactions, Tetrahedron Lett., 2002, 43, 6541; (b) S. M. Yang, J. J. Shie, J. M. Fang, S. K. Nandy, H. Y. Chang, S. H. Lu and G. Wang, Synthesis of Polysubstituted Benzothiophenes and Sulfur-Containing Polycyclic Aromatic Compounds via Samarium Diiodide Promoted Three-Component Coupling Reactions of Thiophene-2carboxylate, J. Org. Chem., 2002, 67, 5208-5215; (c) S. Dong and L. A. Paquette, Stereoselective Synthesis of Conformationally Constrained 2 -Deoxy- $4^{\prime}$-thia $\beta$-Anomeric Spirocyclic Nucleosides Featuring Either Hydroxyl Configuration at $\mathrm{C5}^{\prime}$, J. Org. Chem., 2005, 70, 1580-1596; (d) A. Corsaro, V. Pistara, M. A. Chiacchio, E. Vittorino and R. Romeo, Synthesis of $4^{\prime}$-thionucleosides by 1,3-dipolar cycloadditions of the simplest thiocarbonyl ylide with alkenes bearing electron-withdrawing groups, Tetrahedron Lett., 2007, 48, 4915-4918.

4 (a) H. Kumamoto, T. Nakai, K. Haraguchi, K. T. Nakamura, H. Tanaka, M. Baba and Y. C. Cheng, Synthesis and AntiHuman Immunodeficiency Virus Activity of $4^{\prime}$-Branched ( \pm )-4'-Thiostavudines, J. Med. Chem., 2006, 49, 7861-7867; (b) J. A. Miller, A. W. Pugh and G. M. Ullah, Synthesis of 4thiofuranoid 1,2-glycals and their application to stereoselective synthesis of $4^{\prime}$-thionucleosides, Tetrahedron Lett., 2000, 41, 3265-3268; (c) L. A. Paquette, F. Fabris, F. Gallou and S. Dong, C4'-Spiroalkylated Nucleosides 
Having Sulfur Incorporated at the Apex Position, J. Org. Chem., 2003, 68, 8625-8634; (d) A. C. Ferguson, R. M. Adlington, D. H. Martyres, P. J. Rutledge, A. Cowley and J. E. Baldwin, Total synthesis of a novel 2-thiabicyclo [3.2.0]heptan-6-one analogue of penicillin N, Tetrahedron, 2003， 59，8233-8243; (e) D. H. Martyres, J. E. Baldwin, R. M. Adlington, V. Lee, M. R. Probert and D. J. Watkin, Synthesis of a novel thiabicyclo[3.2.0]heptan-6-one analogue of penicillin, Tetrahedron, 2001, 57, 4999-5007; $(f)$ J. W. Johnson, D. P. Evanoff, M. E. Savard, G. Lange, T. R. Ramadhar, A. Assoud, N. J. Taylor and G. I. Dmitrienko, Cyclobutanone Mimics of Penicillins: Effects of Substitution on Conformation and Hemiketal Stability, J. Org. Chem., 2008, 73, 6970-6986.

5 (a) M. Hanédanian, O. Loreau, F. Taran and C. Mioskowski, $\alpha$-Addition of activated methylenes to alkynoates. A straightforward synthesis of multifunctional compounds, Tetrahedron Lett., 2004, 45, 7035-7038; (b) F. M. Moghaddam, H. Z. Boeini, M. Bagheri, P. Ruedi and A. Linden, Highly efficient and versatile one-pot synthesis of substituted thienylidene compounds, J. Sulfur Chem., 2005, 26, 245-250; (c) P. Gopinath and S. Chandrasekaran, Synthesis of functionalized dihydrothiophenes from doubly activated cyclopropanes using tetrathiomolybdate as the sulfur transfer reagent, J. Org. Chem., 2011, 76, 700-703; (d) A. Kamimura, K. Miyazaki, Y. Yamane, R. Yo, S. Ishikawa, H. Uno and M. Sumimoto, A Radical Cascade Cyclization To Prepare Dihydrothiophenes Induced by Thiyl Radicals as Sulfur Biradical Equivalents, J. Org. Chem., 2013, 78, 7816-7822; (e) G. C. Nandi and M. S. Singh, p-TSA/BasePromoted Propargylation/Cyclization of $\beta$-Ketothioamides for the Regioselective Synthesis of Highly Substituted (Hydro)thiophenes, J. Org. Chem., 2016, 81, 5824-5836; (f) Y. Y. Zhao, S. Zhao, J. K. Xie, X. Q. Hu and P. F. Xu, Synthesis of Spirocyclic Oxindole Dihydrothiophenes by DBU-Catalyzed [3 + 2] Annulation of Morita-Baylis-Hillman Carbonates with Isothiocyanates, J. Org. Chem., 2016, 81, 10532-10537; (g) J. Y. Son, J. Kim, S. H. Han, S. H. Kim and P. H. Lee, Regioselective Synthesis of Dihydrothiophenes and Thiophenes via the Rhodium-Catalyzed Transannulation of 1,2,3-Thiadiazoles with Alkenes, Org. Lett., 2016, 18, 5408-5411.

6 (a) G. Zheng, X. Ma, B. Liu, Y. Dong and M. Wang, IodineCatalyzed Intramolecular Oxidative Thiolation of Vinylic Carbon-Hydrogen Bonds via Tandem Iodocyclization and Dehydroiodination: Construction of 2-Methylene-3thiophenones, Adv. Synth. Catal., 2014, 356, 743-748; (b) Z. Fang, P. Liao, Z. Yang, Y. Wang, B. Zhou, Y. Yang and $\mathrm{X}$. Bi, Synthesis of Dihydrothiophenes and Thiophenes by the Strategic Use of 2-Vinylidene-1,3-dithiolane as a Masked Thiolate Anion, Eur. J. Org. Chem., 2014, 5, 924927; (c) F. Zeng, P. Liu, X. Shao, Z. Li and X. Xu, Catalystfree and selective synthesis of 2-aminothiophenes and 2amino-4,5-dihydrothiophenes from 4-thiazolidinones in water, $R S C A d v ., 2016,6$, 59808-59815.

7 (a) S. M. Yang and J. M. Fang, Reductive double electrophilic reactions of methyl thiophenecarboxylate mediated by samarium diiodide and hexamethylphosphoramide, Tetrahedron Lett., 1997, 38, 1589-1592; (b) S. M. Yang and J. M. Fang, Synthesis of polycyclic and 4,5-diacylthiophene2-carboxylates via intramolecular Friedel-Crafts alkylations and unusual autoxidative fragmentation of the derivatives obtained from the samarium diiodide-promoted coupling reactions of thiophene-2-carboxylate with carbonyl compounds, Tetrahedron, 2007, 63, 1421-1438; (c) S. Urban, B. Beiring, N. Ortega, D. Paul and F. Glorius, Asymmetric Hydrogenation of Thiophenes and Benzothiophenes, J. Am. Chem. Soc., 2012, 134, 15241-15244; (d) P. Tosatti and A. Pfaltz, Iridium-Catalyzed Asymmetric Hydrogenation of Benzo[b]thiophene 1,1-Dioxides, Angew. Chem., Int. Ed., 2017, 56, 4579-4582.

8 (a) T. S. Jagodziński, Thioamides as Useful Synthons in the Synthesis of Heterocycles, Chem. Rev., 2003, 103, 197-227; (b) L. R. Wen, T. He, M. C. Lan and M. Li, ThreeComponent Cascade Annulation of $\beta$-Ketothioamides Promoted by $\mathrm{CF}_{3} \mathrm{CH}_{2} \mathrm{OH}$ : A Regioselective Synthesis of Tetrasubstituted Thiophenes, J. Org. Chem., 2013, 78, 10617-10628; (c) L. R. Wen, L. B. Men, T. He, G. J. Ji and M. Li, Switching regioselectivity of $\beta$-keto thioamides by means of iodine catalysis: Synthesis of thiazolylidenes and 1,4-dithiines, Chem.-Eur. J., 2014, 20, 5028-5033.

9 (a) M. J. Motto, A. Castillo, A. Greer, L. K. Montemayer, E. E. Sheepwash and A. L. Schwan, Synthetic scope, computational chemistry and mechanism of a base induced 5-endo cyclization of benzyl alkynyl sulfides, Tetrahedron, 2011, 67, 1002-1010; (b) J. A. Wilkinson, N. Ardes-Guisot, S. Duckia and J. Leonard, Novel methods for the synthesis of 5-substituted-3-carboxy-2,5-and 4,5dihydrothiophenes and 5-substituted 2- and 3-sulfolenes, Tetrahedron, 2007, 63, 1065-1073; (c) Q. Liao, W. You, Z. B. Lou, L. R. Wen and C. J. Xi, Copper-catalyzed tandem S-alkylation and S-alkenylation of sodium sulfide: synthesis of 2,3-dihydrothiophenes and thiophenes, Tetrahedron Lett., 2013, 54, 1475-1477.

10 (a) J. Sun, L. L. Zhang, E. Y. Xia and C. G. Yan, Synthesis of Dihydrothiophenes or Spirocyclic Compounds by Domino Reactions of 1,3-Thiazolidinedione, J. Org. Chem., 2009, 74, 3398-3401; (b) J. Sun, E. Y. Xia, L. L. Zhang and C. G. Yan, Triethylamine-Catalyzed Domino Reactions of 1,3Thiazolidinedione: Facile Access to Functionalized Dihydrothiophenes, Eur. J. Org. Chem., 2009, 30, 52475254; (c) J. Sun, E. Y. Xia, L. L. Zhang and C. G. Yan, A novel four-component reaction involving ring-opening/ recyclization of 1,3-thiazolidinedione, Sci. China: Chem., 2010, 53, 863-868; (d) J. Sun, E. Y. Xia, Q. Wu and C. G. Yan, Synthesis of ammonium S-S bond linked dipyridinedionates via four-component reactions of cyanoacetamide, aldehyde, amine and 1,3thiazolidinedione, Tetrahedron, 2010, 66, 7794-7798; (e) J. Sun, Q. Wu, E. Y. Xia and C. G. Yan, Diastereoselective Synthesis of trans-2,3-Dihydrothiophenes via Multicomponent Reactions of Pivaloylacetonitrile, Aldehyde, Amine and 1,3Thiazolidinedione, Synthesis, 2010, 23, 3987-3992; (f) J. Sun, E. Y. Xia, Y. Yao and C. G. Yan, Convenient synthesis of 
polyfunctional dihydrothiophenes with tandem reaction of 1,3thiazolidinedione, aldehyde, arylamine and ethyl cyanoacetate, Mol. Diversity, 2011, 15, 115-123.

11 (a) G. P. Lu, L. Y. Zeng and C. Cai, An efficient synthesis of dihydrothiophene ureidoformamides by domino reactions of 1,3-thiazolidinedione under catalyst-free conditions, Green Chem., 2011, 13, 998-1003; (b) A. Kumar, G. Gupta and S. Srivastava, Functional ionic liquid mediated synthesis (FILMS) of dihydrothiophenes and tacrine derivatives, Green Chem., 2011, 13, 2459-2463; (c) D. Q. Shi, Y. Zou, Y. Hu and $\mathrm{H}$. Wu, Improved synthesis of dihydrothiophenes derivatives under ultrasound irradiation, J. Heterocycl. Chem., 2011, 48, 896-900; (d) A. Khazaei, H. Veisi, M. Safaei and H. Ahmadian, Green synthesis of 5-arylidene-2,4-thiazolidinedione, 5benzylidene rhodanine and dihydrothiophene derivatives catalyzed by hydrated ionic liquid tetrabutylammonium hydroxide in aqueous medium, J. Sulfur Chem., 2014, 35, 270278.

12 (a) D. Teng, S. Xia, S. M. Tao, L. J. Gao, Y. J. Feng and L. C. Rong, An efficient synthesis of 3-aryl-2,3dihydrothiophene-2-carboxamide derivatives by one-pot, four-component reaction, Res. Chem. Intermed., 2013, 39, 561-568; (b) L. J. Gao, S. Xia, N. Wu, S. M. Tao, Y. J. Feng and L. C. Rong, Efficient preparation of 5-amino-4-cyano- $N$ (cyclopropylcarbamoyl)-3-aryl-2,3-dihydrothiophene-2carboxamide derivatives without using any other catalysts, Synth. Commun., 2013, 43, 2590-2595; (c) J. P. Zhang, Y. N. Gao, M. Chen, L. Jiang, S. Xia and L. C. Rong, An efficient synthesis of 2,3-dihydrothiophene derivatives from four-component reactions under catalyst-free conditions, Chin. J. Org. Chem., 2014, 34, 1895-1899. 